\title{
Some hematology and blood chemistry parameters of the Pacific fat sleeper Dormitator latifrons (Richardson, 1844)
}

\author{
Luis Eduardo Ruiz-González ${ }^{1}$, Fernando Vega-Villasante ${ }^{1}$, Adrián Tintos-Gómez ${ }^{1,2}$ \\ Oscar Basilio Del Rio-Zaragoza ${ }^{3}$, Mónica Hernández-Rodríguez ${ }^{4}$ \\ Manuel Patiño Barragán ${ }^{2}$ \& Daniel Badillo-Zapata ${ }^{1}$ \\ ${ }^{1}$ Laboratorio de Calidad de Agua y Acuicultura Experimental, Departamento de Ciencias Biológicas \\ Centro Universitario de la Costa, Universidad de Guadalajara, Puerto Vallarta, Jalisco, México \\ ${ }^{2}$ Facultad de Ciencias Marinas, Universidad de Colima, Manzanillo, México \\ ${ }^{3}$ Instituto de Investigaciones Oceanológicas, Universidad Autónoma de Baja California \\ Ensenada, Baja California, México \\ ${ }^{4}$ Centro de Investigación Científica y de Educación Superior de Ensenada \\ Ensenada, Baja California, México \\ Corresponding author: Adrián Tintos-Gómez (atintos48@gmail.com)
}

\begin{abstract}
Dormitator latifrons is an amphidromous fish species distributed on the Pacific coastal region from California to Peru. It has a high potential to be cultured in Mexico. However, there is very little information about its biology, physiology and culture. This research study is a contribution to the hematology and blood chemistry of this native species. Results show hematocrit values of $28 \%$, erythrocytes $2.075 \times 10^{6} \mathrm{~mm}^{3}$, leukocytes $35.035 \times 10^{3} \mathrm{~mm}^{3}$, mean corpuscular volume $161.547 \mathrm{fL}$, NBT 0.39 , glucose $51.467 \mathrm{mg} \mathrm{dL}^{-1}$, protein $3.936 \mathrm{~g} \mathrm{dL}^{-1}$, albumin $1.906 \mathrm{~g} \mathrm{dL}^{-1}$, globulin $2.391 \mathrm{~g} \mathrm{dL}^{-1}$ and albumin/globulin ratio 0.686 .
\end{abstract}

Keywords: Dormitator latifrons; amphidromous fish; hematology; blood chemistry

The Pacific fat sleeper Dormitator latifrons (Richardson, 1844) is distributed on the Pacific slope from California to Peru (Vicuña, 2010). D. latifrons is an amphidromous fish, so it spawns in freshwater and larvae migrate to brackish water and then return to freshwater bodies (Milton, 2009), besides, is an omnivorous fish; however, it feeds mainly on detritus particles (Yáñez-Arancibia \& Díaz-González, 1977). The species is characterized by its pigmentation from blue-green to green-red in the dorsal area. Bluish sidebands. Slate-colored skull, bluish in the ventral area. Pale gray belly. Gray dorsal fin with black spots and red stripe. Green anal fin at its base with dark spots on edge (Kähsbauer, 1973).

The production of D. latifrons represents an alternative source of income, being able to grow in extensive systems with artisanal methodologies, obtaining good growing results, mainly in the monosex male culture (Castro-Rivera et al., 2005). Also, because it is a white meat fish with high protein content, it can be considered as a key product for a developing market (Vicuña, 2010).

In order to properly perform this culture, it is necessary to monitor the health of the organisms constantly, and this could be done through blood tests. Hematology and blood chemistry are an essential tool for the diagnosis of diseases produced from environmental changes, nutritional imbalance, or even the presence of pathogens (Stoskopf, 1993; Hrubec \& Smith, 2010).

Although this fish has characteristics that make it an excellent candidate for aquaculture in Mexico and most Latin America, there is little information on different aspects of its physiology. In the case of hematology and blood chemistry, the information is limited, with the exception of the research by Todd (1972), where the hematocrit $(39.1 \pm 6.1 \%)$, red blood cell count $(3.2 \pm$ $\left.0.5 \times 10^{6} \mathrm{~mm}^{3}\right)$, mean corpuscular volume $(122.8 \pm 6.1$ fL), the hemoglobin concentration $(15.5 \pm 2.7 \%)$, the mean corpuscular hemoglobin $(48 \pm 61.5 \mu \mathrm{g})$ and the

Corresponding editor: Crisantema Hernández 
corpuscular media hemoglobin concentration $(40.5 \pm$ $1.8 \%)$ were documented. For this reason, the main objective of this research is to contribute with some hematological and blood chemistry parameters of this fish.

D. latifrons (30 fish, $13 \pm 1 \mathrm{~cm}$ of total size, $33.8 \pm$ $3.7 \mathrm{~g}$ weight) were collected from El Quelele Estuary, Banderas Bay, Nayarit, Mexico $\left(20^{\circ} 43^{\prime} 54.2^{\prime} \mathrm{N}\right.$, $105^{\circ} 18^{\prime} 07.5^{\prime \prime} \mathrm{W}$ ), with the help of a $3 \mathrm{~cm}$ diameter light mesh net. Organisms were kept in quarantine for 30 days. Subsequently, fish were placed in $400 \mathrm{~L}$ tanks, five fish per tank, connected to a recirculation system with a bio-filter and a UV light system. The organisms were acclimated for seven days. During the acclimation and the bioassay, fish were exposed to a photoperiod of $12 \mathrm{~h}$ light: $12 \mathrm{~h}$ darkness, at temperatures of 26.5 to $28^{\circ} \mathrm{C}$, oxygen with a concentration $\geq 5 \mathrm{mg} \mathrm{L}^{-1}$ and a $\mathrm{pH}$ from 7 to 8.

Purina ${ }^{\circledR}$ brand commercial feed with $35 \%$ protein and $8 \%$ fat (for tilapia, $3.5 \mathrm{~mm}$ particle size) was used. Food was administered in three daily rations at 9, 13 and $17 \mathrm{~h}$, for four weeks, under the conditions described above. The first biometry was performed to adjust the amount of food concerning $4 \%$ of the biomass. At the end of week four, the blood samples of fish were collected as described below. All fish used were healthy and without parasites. Besides, fish did not show any sign of sexual maturation, such as changes in the genital papilla or abdomen coloration (Bonifaz et al., 1985).

Organisms were anesthetized with clove oil, previously dissolved in ethanol in a 1:10 ratio (Javahery et al., 2012). Blood samples were taken from the caudal vein, with a $3 \mathrm{~mL}$ syringe, without anticoagulant. A minimum sample of $1,000 \mu \mathrm{L}$ per fish was obtained. Half of the sample $(500 \mu \mathrm{L})$ was placed in a tube with EDTA-K2 anticoagulant, and the other half in Eppendorf ${ }^{\circledR}$ vials without anticoagulant, for subsequent analyses.

Blood samples with EDTA-K2 were used for hematocrit (hct), red blood cell counts (RBC), white blood cell counts (WBC) and respiratory burst analysis. Hct was realized from blood samples with EDTA-K2, glass capillaries were filled with about $60 \mu \mathrm{L}$ and sealed at one end, centrifuged at 4,000 $\mathrm{g}$ for $10 \mathrm{~min}$ in Scilogex DM1424 centrifuge. Hct percentage was determined by a circular hematocrit reader.

For the respiratory burst analysis, the Ibrahem et al. (2010) method was used, which consisted in placing $100 \mu \mathrm{L}$ of blood with EDTA-K2 in plastic vials (Eppendorf $^{\circledR}$ ), added $100 \mu \mathrm{L}$ of Nitro-blue Tetrazolium (NBT) solution at $0.2 \%$ and incubated for $30 \mathrm{~min}$ at room temperature. Subsequently, $50 \mu \mathrm{L}$ of the mixture was taken and placed in $1 \mathrm{~mL}$ of $\mathrm{N}, \mathrm{N}$-dimethyl formamide, and then centrifuged at 2,000 $\mathrm{g}$ for $5 \mathrm{~min}$ in Ika mini G 3958000 centrifuge. The supernatant was recovered and analyzed in a Velab VE - $5000 \mathrm{~V}$ spectrophotometer, in $1 \mathrm{~mL}$ glass cells, at $620 \mathrm{~nm}$.

For total cell counts, a sample of $20 \mu \mathrm{L}$ of blood with EDTA-K2 was placed in $4 \mathrm{~mL}$ of Natt-Herrick solution. A Neubauer chamber with $1 / 400 \mathrm{~mm}^{2}$ and $1 / 10 \mathrm{~mm}$ deep, was filled with $5 \mu \mathrm{L}$ of the dilution. The analysis was carried out by observation in a Quasar Qm20 Binocular 2500x Professional Microscope. The $\mathrm{RBC}$ was performed in the central grid, from which five squares of $0.0025 \mathrm{~mm}^{2}$ each were selected, and the WBC in four large squares, from each corner, with an area of $1 \mathrm{~mm}^{2}$ each. With the RBC and hct, the mean corpuscular volume (MCV) was calculated by the formula: $\mathrm{MCV}=($ het $\times 10) /$ number of erythrocytes (millions $\mathrm{mm}^{3}$ ).

The sample with no anticoagulant was centrifuged for $10 \mathrm{~min}$ at 2,000 $\mathrm{g}$ for $5 \mathrm{~min}$ in Ika mini G 3958000 . The resulting serum was recovered in a plastic vial (Eppendorf $^{\circledR}$ ) and used to blood chemical assays. Kits $\left(\right.$ Mexlab $\left.^{\circledR}\right)$ were used for albumin (BCG, $620 \mathrm{~nm}$ ), glucose (God-Pad, $505 \mathrm{~nm}$ ), and total protein (Biuret, $540 \mathrm{~nm}$ ), and the absorbance was recorded by spectrophotometry. Globulin was calculated by difference concerning albumin and total protein, and albumin/globulin rate $(\mathrm{A} / \mathrm{G})$ was determined.

Shapiro Wilk normality tests were performed for each of the measured parameters. Besides, the reference intervals were calculated by twice the standard deviation (Stoskopf, 1993).

At the end of 30 days under the conditions described above, the organisms reached a size of $14.5 \pm 0.6 \mathrm{~cm}$, and a mean weight of $43.1 \pm 6.9 \mathrm{~g}$. Table 1 shows the results of the blood chemistry and hematology studies in D. latifrons. The reference intervals are established. The results of hematocrit, respiratory burst (NBT), glucose, total proteins, albumins and globulins showed a normal distribution $(P>0.05)$. In contrast, the RBC and WBC did not meet the normality assumptions.

Studies of blood parameters in fish is a widely documented subject with different objectives, taking into account the season of year, physical stress (temperature and salinity), contaminants, transport, nutritional aspects, crop densities and presence of diseases, among others; since they allow us to know the physiological state of the organisms (Stoskopf, 1993; Roche \& Bogué, 1996; Hrubec et al., 2000; Kumar et al., 2005; Saravanan et al., 2011; Cengizler et al., 2017).

The hct, RBC and WBC are the hematology parameters most analyzed in blood fish studies. The hct of D. latifrons (28.08\%) is higher than that of Sorubim 
Table 1. Hematological parameters, blood chemistry and reference intervals of Dormitator latifrons. SD: standard deviation, RBC: red blood cell, WBC: white blood cell, MCV: mean corpuscular volume, NBT: Nitro-blue tetrazolium.

\begin{tabular}{|c|c|c|}
\hline Parameter & Mean \pm SD & Reference interval \\
\hline Hematocrit (\%) & $28.083 \pm 8.490$ & $11.103-45.064$ \\
\hline $\mathrm{RBC} \times 10^{6}\left(\right.$ cells mm $\left.{ }^{3}\right)$ & $2.075 \pm 0.449$ & $1.177-2.973$ \\
\hline $\mathrm{WBCs} \times 10^{3}\left(\right.$ cells $\left.\mathrm{mm}^{3}\right)$ & $35.035 \pm 7.012$ & $21.011-49.059$ \\
\hline MCV (fL) & $161.547 \pm 34.996$ & $91.555-231.539$ \\
\hline NBT & $0.39 \pm 0.080$ & $0.230-0.550$ \\
\hline Glucose $\left(\mathrm{mg} \mathrm{dL}^{-1}\right)$ & $51.467 \pm 8.418$ & $34.630-68.304$ \\
\hline Total protein $\left(\mathrm{g} \mathrm{dL}^{-1}\right)$ & $3.936 \pm 0.840$ & $2.256-5.616$ \\
\hline Albumin $\left(\mathrm{g} \mathrm{dL}^{-1}\right)$ & $1.906 \pm 0.784$ & $0.339-3.474$ \\
\hline Globulins $\left(\mathrm{g} \mathrm{dL}^{-1}\right)$ & $2.391 \pm 0.266$ & $1.859-2.922$ \\
\hline A/G ratio & $0.686 \pm 0.191$ & $0.304-1.068$ \\
\hline
\end{tabular}

cuspicaudus (22.70\%) (Correa-Negrete et al., 2009). Both het are lower than those of $O$. niloticus $(32.44 \%)$ at a mean temperature of $27^{\circ} \mathrm{C}$ (Hahn-von-Hessberg et al., 2014), similar to that of the present study as described by Larsson et al. (1976), the low percentages of Hct, corresponding to benthic, sedentary or slowmoving species.

In contrast, $S$. cuspicaudus has a higher value of RBC and WBC than D. latifrons (Correa-Negrete et al., 2009). Nevertheless, S. cuspicaudus showed the lowest MCV $(11.5 \pm 2.2 \mathrm{fL})$ than D. latifrons $(161.54 \mathrm{fL})$. That is because $S$. cuspicaudus presented small erythrocytes. Additionally, D. latifrons showed an erythrocyte number higher than those reported for O. niloticus (1.70 $\left.\pm 0.4 \times 10^{6} \mathrm{~mm}^{3}\right)$ and similar to that of Rhamdia quelen $2.11 \pm 0.6 \times 10^{6} \mathrm{~mm}^{3}$ ) (Dal' Bó et al., 2015). The MCV of $O$. niloticus and $R$. quelen is similar to that found in this study for D. latifrons.

In the case of NBT (Nitroblue Tetrazolium), this is used to evaluate the respiratory burst, in this case, by reducing the NBT by surrounding leukocytes. $D$. latifrons, under the established conditions, showed an absorbance of 0.39 , higher than $O$. niloticus with balanced feed (0.173), and even higher than those that received diets with inulin (0.233) and vitamin $\mathrm{C}(0.277)$ (Ibrahem et al., 2010). The preceding indicates that $D$. latifrons has higher activity of respiratory burst, which could provide greater protection against infectious diseases.

The blood chemistry comparison of hybrid tilapia individuals (Oreochromis niloticus $\times$ O. mossambicus $\times O$. aureus $)$ in two culture densities, high $(\mathrm{n}=63)$ and low $(\mathrm{n}=15)$ was performed. Where for the first, a concentration of $3.9 \mathrm{~g} \mathrm{dL}^{-1}$ of total proteins, $1.8 \mathrm{~g} \mathrm{dL}^{-1}$ of albumins, $2.1 \mathrm{~g} \mathrm{dL}^{-1}$ of globulins and $46 \mathrm{mg} \mathrm{dL}^{-1}$ of glucose values were found. The hybrid tilapia cultivated at low density showed lower values of total proteins, albumins and globulins (2.9, 1.2 and $1.6 \mathrm{~g} \mathrm{dL}^{-1}$, respectively); however, a glucose concentration of 52 $\mathrm{mg} \mathrm{dL}^{-1}$ was found (Hrubec et al., 2000). The results of the high-density culture are similar to those found in this research study for D. latifrons, although this fish was found in much lower densities, which suggests that differences could be observed about culture densities of D. latifrons.

Likewise, species Carassius auratus and Pterois volitans show blood chemistry values similar to those found for D. latifrons in this study; for the first one, glucose values of $34.5 \mathrm{mg} \mathrm{dL}^{-1}$, total proteins $2.84 \mathrm{~g}$ $\mathrm{dL}^{-1}$, albumin $2.13 \mathrm{~g} \mathrm{dL}^{-1}$ and globulins $0.7 \mathrm{~g} \mathrm{dL}^{-1}$ (Adamovicz et al., 2015); for the second one, glucose $26.5 \mathrm{mg} \mathrm{dL}^{-1}$, total proteins $4 \mathrm{~g} \mathrm{dL}^{-1}$, albumins $1 \mathrm{~g} \mathrm{dL}^{-1}$ and globulins $2.9 \mathrm{~g} \mathrm{dL}^{-1}$ (Anderson et al., 2010). However, in both cases, D. latifrons shows a higher glucose concentration. It should be noted that organisms studied by Anderson et al. (2010) were obtained from a population maintained for reproductive physiology studies. On the other hand, Adamovicz et al. (2015) used sexually immature organisms, like the ones in this study.

D. latifrons showed similar characteristics to those of the Metriaclima greshakei species, except for the level of albumins (albumin of $0.95 \mathrm{~g} \mathrm{dL}^{-1}$ ) and, therefore, globulins $\left(2.9 \mathrm{~g} \mathrm{dL}^{-1}\right)$, where observed that $D$. latifrons, under the conditions established in this study, shows almost double the concentration of albumins $\left(1.906 \mathrm{~g} \mathrm{dL}^{-1}\right)$. However, the authors mention that despite reporting a low level of albumins, which may be associated with liver disease, it did not appear in their study. Also, it should be noted that the authors did not anesthetize their organisms and made the sampling only covering the fish's eyes (Snellgrove \& Alexander, 2011). 
Todd (1972) describes an hct, RCB and MCV higher than the results of this research for D. latifrons. However, the fishes used in Todd (1972) were weighing 150-350 g, and the fishes used in this research has less weight $(43.1 \mathrm{~g})$. In other species, significant differences have been found in some hematological parameters between different cultivation systems and individuals of the natural environment, as is the case of Christoma estor estor, which showed significant differences in the hematocrit and hemoglobin concentration among organisms coming from of the natural environment and three farming systems (Alaye-Rahy \& Morales-Palacios, 2013). Likewise, it has been demonstrated that seasonal changes affect the hematology and blood chemistry of fish, such as $O$. niloticus (Cengizler et al., 2017). Also, the sexual differentiation that was found in the blood chemistry of Oncorhynchus mykiss (Qadir-Charoo et al., 2013). The above suggests the possibility of observing these same differences in D. latifrons.

Results of this research work show that in general, the hematological and blood chemistry parameters found for D. latifrons are similar to those of other freshwater species. Also, D. latifrons showed higher activity in the respiratory burst, which suggests greater resistance to infections. This first approach to the hematology and blood chemistry of D. latifrons is a contribution of importance to the knowledge of the species, so this research lays the basis for further studies.

\section{REFERENCES}

Adamovicz, L.A., Trosclair, M.R. \& Lewbart, G.A. 2015. Biochemistry panel reference intervals for juvenile goldfish (Carassius auratus). Journal of Zoo and Wildlife Medicine, 48: 776-785.

Alaye-Rahy, N. \& Morales-Palacios, J.J. 2013. Parámetros hematológicos y células sanguíneas de organismos juveniles del pescado blanco (Christoma estor estor) cultivados en Páztcuaro, Michoacán, México. Hidrobiológica, 23: 340-347.

Anderson, E.T., Stoskopf, M.K., Morris, J.A., Clarke, E.O. \& Harms, C.A. 2010. Hematology, plasma biochemistry, and tissue enzyme activities of invasive red lionfish captured off North Carolina, USA. Journal of Aquatic Animal Health, 22: 266-273.

Bonifaz, N., Campos, M. \& Castelo, R. 1985. El chame, una nueva fuente de alimentación e ingresos. Fundación Ciencia para el Estudio del Hombre y de la Naturaleza, Quito.

Castro-Rivera, R., Aguilar-Benítez, G. \& HernándezGirón, J.P. 2005. Conversión alimenticia en engordas puras y mixtas de popoyote (Dormitator latiforns
Richardson) en estanques de cemento. Revista AquaTIC, 23: 45-52.

Cengizler, I., Küçükgül, A. \& Şaş, G. 2017. Seasonal changes in some hematological parameters in association with acted in oxygen transport in Nile tilapia (Oreochromis niloticus L). Eastern Anatolian Journal of Science, 3: 6-13.

Correa-Negrete, J.C., Garrido-Correa, A.A., PrietoGuevara, M.J., Atencio-García, V.J. \& Pardo-Carrasco, S.C. 2009. Caracterización de células sanguíneas y parámetros hematológicos en blanquillo Sorubim cuspicaudus. Zootecnia Tropical, 27: 393-405.

Dal'Bó, G.A., Garcia-Sampaio, F., Losekann, M.E., Ferraz de Queiroz, J., Barreto-Luiz, A.J., GyárfasWolf, V.H., Teodoro-Gonçalves, V. \& Carra, M.L. 2015. Hematological and morphometric blood value of four cultured species of economically important tropical foodfish. Neotropical Ichthyology, 13: 439446.

Hahn-von-Hessberg, C.M., Quiroz-Bucheli, A. \& Grajales-Quintero, A. 2014. Caracteres hematológicos en individuos de tilapia nilotica (Oreochromis niloticus, Trewavas, 1983) con pesos entre 50-150 g y 150-250 g, Estación Piscícola, Universidad de Caldas, Colombia. Boletín Científico Museo de Historia Natural de Universidad de Caldas, 18: 142-157.

Hrubec, T.C., Carnidale, J.L. \& Smith, S.A. 2000. Hematology and plasma chemistry reference intervals for cultured tilapia (Oreochromis hybrid). Veterinary Clinical Pathology, 29: 7-12.

Hrubec, T.C. \& Smith, S.A. 2010. Hematology of fishes. In: Weiss, D.J. \& Wardrop, K.J. (Eds.). Schalm's veterinary hematology. Wiley-Blackwell Publishing, New Jersey, pp. 994-1003.

Ibrahem, M.D., Fathi, M., Mesalhy, S. \& El-Aty, A.M. 2010. Effect of dietary supplementation of inulin and vitamin $\mathrm{C}$ on the growth, hematology, innate immunity, and resistance of Nile tilapia (Oreochromis niloticus). Fish and Shellfish Immunology, 29: 241246.

Javahery, S., Nekoubin, H. \& Moradlu, A.H. 2012. Effect of anesthesia with clove oil in fish (review). Fish Physiology and Biochemistry, 38: 1545-1552.

Kähsbauer, P. 1973. Über einige centralamerikanische Siluriden und Grobiiden. Annalen des Naturhistorischen Museums in Wien, 77: 263-273.

Milton, D.A. 2009. Living in two worlds: diadromous fishes, and factors affecting population connectivity between tropical rivers and coasts. In: Nagelkerken, I. (Ed.). Ecological connectivity among tropical coastal ecosystems. Springer, Berlin, pp. 325-355. 
Qadir-Charoo, S., Rauoof-Chalkoo, S. \& Qureshi, T.A. 2013. Sexual differentiation in blood biochemistry of rainbow trout (Oncorhynchus mykiss). International Journal of Advanced Fisheries and Aquatic Science, 1: 32-38.

Snellgrove, D.L. \& Alexander, L.G. 2011. Haematology and plasma chemistry of the red top ice blue mbuna cichlid (Metriaclima greshakei). British Journal of Nutrition, 106: 154-157.

Stoskopf, M.K. 1993. Clinical pathology. In: Stoskopf, M.K. (Ed.). Fish medicine. Saunders, Philadelphia, pp. 113-131.

Received: 16 April 2019; Accepted: 22 July 2019
Todd, E.E. 1972. Hemoglobin concentration in a new airbreathing fish. Comparative Biochemistry and Physiology Part A: Physiology, 42: 569-573.

Vicuña, O. 2010. Dormitator latifrons (Chame). In: Flores-Nava, A. \& Brown, A. (Eds.). Peces nativos de agua dulce de América del Sur de interés para la acuicultura: una síntesis del estado de desarrollo tecnológico de su cultivo. FAO, Serie Acuicultura en Latinoamérica, 1: 63-70.

Yáñez-Arancibia, A. \& Díaz-González, G. 1977. Ecología trofodinámica de Dormitator latifrons (Richardson) en nueve lagunas costeras del Pacífico de México (Pisces: Eleotridae). Anales del Centro de Ciencias del Mar y Limnología, Universidad Nacional Autónoma de México, 4(1): 125-140. 